\title{
Strategy for Empowering Poor Families through an Integrated Program to Increase the Role of Women towards Prosperous Healthy Families in Depok, West Java
}

\author{
Dhea Ariesta Khairunnisa ${ }^{1}$, Khaerul Umam Noer ${ }^{2}$ \\ \{dheariesta94@gmail.com¹, umam.noer@umj.ac.id ${ }^{2}$ \} \\ Universitas Muhammadiyah Jakarta, Indonesia ${ }^{1,2}$
}

\begin{abstract}
This study aims to analyze the implementation of the Program for Increasing the Role of Women Towards Healthy Families conducted by the Government in Cipayung, Depok, West Java. The program is aimed at reducing poverty, especially among women household heads through increasing the role of women who use a crosssectoral approach to development in a coordinated manner, with efforts directed at increasing family welfare to achieve high standards of living. By using the seven stages of community empowerment, this research found several things, including: the involvement of women in the determination of the program to be run is still very limited - they are only involved in the implementation of the program, there are no indicators of program achievement, and unclear program sustainability as a result of fragmentation of local government policies.
\end{abstract}

Keywords: Poor Families, Female Heads Household, Empowerment, Community Development, Public Policy.

\section{Introduction}

Poverty is a condition of economic inability to meet the standard of living of the average community in an area. This inability condition is characterized by the low ability of income to meet basic needs in food, clothing, and shelter. In principle, the standard of living in a society is not just the fulfillment of the need for food, but also the need for health and education [1][2]. Adequate housing or settlement is one of the standard of living or community welfare standards in an area [3]. Until March 2010, the number of poor people in Indonesia reached 31.02 million or $13.33 \%$ of the total population of Indonesia.

Currently, there are an estimated 48 thousand poor people in Depok, out of a total population of 2 million [4][5]. This amount is difficult to reduce significantly, so for this reason, one of the efforts of Depok City Government is to reduce poverty by running an integrated program to Increase the Role of Women Towards Healthy and Prosperous Families (Peningkatan Peranan Wanita menuju Keluarga Sehat Sejahtera or P2WKSS [hereinafter, the Program briefly]). According to Depok Mayor Regulation Number 5/2017 Article 1 point 5, the Program aims to increase the role of women who use a cross-sectoral approach to development, in a coordinated manner, with efforts that are directed to improve family welfare 
to achieve a high quality of life. The implementation of the Program is intended as one of the efforts to increase the role of women in development to realize the quality of the families.

The Program in Cipayung Subdistrict was carried out in several villages, one of which was in Ratu Jaya Village, Cipayung Village, Depok City. In 2018 Ratujaya Village represented Depok City in the top 5 nominations for the Program competition in West Java. Furthermore, in 2019 the Program will be held again in Cipayung Subdistrict, one of which is in Cipayung Village, Cipayung Subdistrict. Currently, the Cipayung Subdistrict needed to get special attention, considering the Human Development Index is still had to catch up to other subdistricts in the City of Depok. As for the community association (Rukun Warga or RW) that have been selected for the Program in Cipayung Village, among others; RW 001, RW 002, RW 009, RW 010 and RW 11. This is certainly different from Ratu Jaya Subdistrict which only focuses on one RW but in Cipayung was expanded to five RWs to obtain the Program. In addition to the Program is to increase HDI equally, the Program is also a place for poor housewives to develop with the training and counseling provided.

For that reason, with the empowerment program, it is expected that housewives as the spearhead in the family in managing all types of family needs can be facilitated to help the economy of poor families [2][6]. The activity is expected to help the economy of underprivileged families to be prosperous and to improve the quality of life of underprivileged families. For this reason, this research will examine how the empowering of the poor family via the Integrated Program to Increase the Role of Women Towards Prosperous Healthy Families or P2WKSS in Cipayung Subdistrict, Depok City.

\section{Research Methods}

In this study, the authors used a qualitative approach. Bodgan and Taylor [7] define qualitative methodology as a research procedure that produces descriptive data in the form of written or verbally from people and observable behavior. This qualitative approach was chosen based on research objectives that want to get a picture of the community/non-formal organization in providing empowerment programs and the benefits of the existence of the empowerment program for the people who receive it [8][9].

This study uses the purposive model to determine and select informants [10]. This explains the informants are people who are used to provide information about the situation and conditions of the research background. This research is located in Ratu Jaya Village and Cipayung Village, Cipayung Subdistrict, Depok City. Data collection techniques were carried out by direct observation at the location of the research took place, then proceed with other techniques. The data collection techniques used in this research are the observation of participation, interviews, study of documentation and literature. Observation is carried out for direct or indirect observation and look carefully at the object to be examined, noting the real thing and is needed indirect data collection. In qualitative research, interviews become the main data collection method [11][12]. According to Creswell [13] interview is that researchers can conduct face to face interviews with participants, this method is used by researchers to collect data or documents that support research. 


\subsection{The P2WKSS Integrated Program Policies}

The Program for Increasing the Role of Women Towards Healthy Families is one program that is an effort to increase the role of women in society towards a prosperous family. Following the vision of the City of Depok as a superior, comfortable and religious city, so the poverty alleviation program is one of the strategies to improve the welfare of the community [11]. Through strategies and policy directions for increasing food security, social welfare services, and alleviating poverty and unemployment, efforts to improve community welfare can be achieved through the implementation of the Program, because one of the goals is to create and develop healthy and prosperous families including the protection of women and children with improving the position, role, ability, independence and mental and spiritual endurance of women through cross-sectoral development activities in the context of community development in disadvantaged areas [2][14].

The main target of the Program is poor families in rural/urban villages with women as the main targets. Women who become participant criteria are women aged 15-64 years with a low level of welfare and or who fall into the category of poor families, underprivileged families with low welfare levels and according to the results of the Central Statistics Agency (Badan Pusat Statistik or BPS). Poverty is very complex, related to various aspects of human life and society. Where the scope of this program is related to socio-economic conditions, health and education.

According to its substance poverty is divided into absolute poverty and relative poverty. Absolute poverty is determined based on the ability to meet basic needs. The Central Statistics Agency explains the minimum basic needs such as food, clothing, health, housing and education needed to be able to live and work translate into financial measures in the form of money. Then, the Program is a women's improvement program that uses a coordinated crosssector approach to development that is directed to improve family welfare to achieve a quality standard of living based on the Laws of Law as follows:

1. Law Number 15 of 1999, concerning the Establishment of the Second Level Region of Depok

2. Law Number 36 of 2009 concerning Health

3. Law Number 52 of 2009 concerning Population Development and Family Development

4. Law number 23 of 2014 concerning Regional Government

5. Minister of Home Affairs Regulation Number 26 of 2009 concerning Guidelines for Implementing the Improvement of the Role of Women Towards Prosperous Healthy Families

6. Permendagri number 01 of 2013 concerning Community Empowerment through the Empowerment and Family Welfare Movement

7. The decision of the Mayor of Depok Number: 591/98/Kpts/DPAPMK/Law/2018 concerning the Determination of the Integrated Program Development Site for the Role of Women towards Prosperous Families in Depok 2018

8. The decision of the Mayor of Depok Number: 821.29/202/Kpts/DPAPMK/Huk/ 2018 concerning the Establishment of a Management Team and Secretariat of the Integrated Program for Increasing the Role of Women towards the Healthy and Prosperous Family of Depok City.

The Program is an ongoing program to increase the family economy, improve the level of family health through a clean and healthy lifestyle, and the ability to realize a 12-year 
compulsory education program for school-age children. The Program is one of the Women's Role Enhancement Programs in Development in the City of Depok that seeks to develop human and natural resources as well as the environment to realize and develop prosperous and happy healthy families in the context of developing rural communities with women as the main sector [14].

\section{Result and Discussion}

By definition, empowerment is defined as an effort to provide empowerment or strengthening to the community [15][16][17]. Community empowerment is defined as the ability of individuals who animate with the community in building the empowerment of the people [18]. Empowerment is a process so that everyone becomes strong enough to participate in various controls, and influences events and institutions that affect their lives [19]. Empowerment emphasizes that people gain enough skills, knowledge, and power to influence their lives and the lives of others they care about [20].

The implementation of the Program which is the subject of the program itself is the Community of Cipayung Subdistrict, particularly the Ratu Jaya Village and the Cipayung Village. Therefore, in implementing the Program, active participation from the community in participating in the activities that will be provided is needed. In this case, also Regional Apparatus Organization (Organisasi Pemerintah Daerah or OPD) has an important role in the implementation of the Program. For this reason, it is necessary to know that in implementing a program, there are steps that need to be taken from the planning, implementation, and evaluation so that the program runs well.

In general, there are seven stages carried out in community empowerment according to Adi [18][15]. Henceforth, the seven stages of the Program empowerment will be carried out in the Ratu Jaya and Cipayung Villages, as follows:

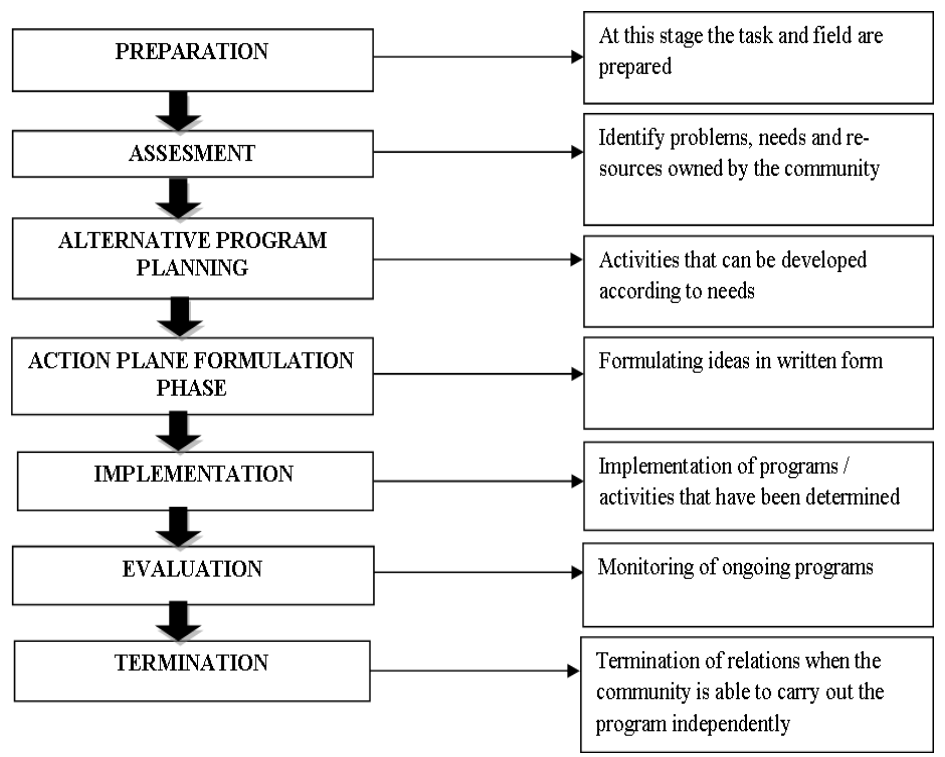

Picture 1. The seven stages of community empowerment [18][15]. 


\subsection{Preparation}

At this stage, the task and field are prepared. The staff preparation is intended to equalize the perception among the change agent team members regarding what approach is chosen in carrying out community development. In preparation, before the implementation of the Program, the Regional Apparatus Organization or the local Dinas first held a coordination meeting at the Depok City level together with Development Planning Agency at Sub-National Level (Badan Perencanaan Pembangunan Daerah or Bappeda), to make the Program budgeting. This was done to see and study how the development of HDI of Cipayung Subdistrict was classified as low. Then look at the Integrated Database Data to find out how many underprivileged residents are in Cipayung Subdistrict, particularly the Ratu Jaya and Cipayung Village. With this in mind, the planning will be carried out on the determination of the Program to be carried out. Afterward, the relevant Regional Apparatus Organization organized a team for the implementation of the Program in the Cipayung Subdistrict.

\subsection{Assessment Phase}

Next stage is the assessment, which is carried out by identifying problems, perceived needs or the self needs of the Program target and also the resources they have. In this process, the relevant Regional Apparatus Organization conducts a survey first. Through the village level, the Regional Apparatus Organization then coordinated the determination of the Program. Henceforth, the village will go down through the hamlet (Rukun Tetangga or RT) and neighborhood (Rukun Warga or RW) to further examine and see the potential of human resources in each village. The Regional Apparatus Organization at the village will make a list of activities that will be carried out for the next and will be communicated to housewives from poor families as targets in the implementation of the Program.

\subsection{Alternative Program Planning}

At the alternative planning stage of the program or activity, staff will try to involve citizens to think about the problems they face and how to overcome them. In this case, the village also held a meeting with the local community to further discuss whether the activities listed by the village were of interest to housewives from poor families' target. Henceforth, the Program target responds to the activities to be carried out. At this meeting also became the beginning of determining what activities will be carried out in each village.

Each village has different activities according to the interests of housewives. As in the village of Ratu Jaya, those housewives from poor family's target attend the Women Farmers Group (Kelompok Wanita Tani or KWT) activities such as creating the hantaran (gift from a bride to groom at wedding ceremony), processed food, traditional Betawi cakes, makeup, and embroidery. Whereas in Cipayung Village, Women Farmers Group activities were held, such as making submissions, cooking/processed snacks, and sewing.

\subsection{Action Plan Formulation Phase}

At this stage, the officer helps each community group to formulate their ideas in written form, especially if it has to do with making proposals to the funding party. At this stage, the proposal or funding is carried out by the village. And the budget has been set by the Office of the Women's and Family Empowerment the City of Depok, because it was long before the 
Program activities would be carried out, the budget would be made first. For this reason, at this stage, the program can be carried out with a budget that has been budgeted by the Office. In this stage, the housewives have started participating in socialization activities, there will be training to be given. Through stakeholders in the community such as hamlet and neighborhood, Posyandu cadres began to integrate the housewives to participate in training activities organized by the Program.

\subsection{Program Implementation/Implementation Stage}

After the plan is arranged, it is continued with the stages of implementation of the program/activity. The implementation phase of this activity went well. Planning activities that have been made can be implemented well. The relevant service authorities provide training to each housewife with the facilities and infrastructure that has been provided. In this case, the participation of housewives is very good by participating in training activities until this activity is completed within the allotted time. This was also said by those participating in the activity felt they had gained more knowledge and could increase their abilities because it was under their respective interests.

\subsection{Evaluation}

The evaluation phase is the process of oversight by the management of the institution and officers of the ongoing program. This evaluation is carried out by related agencies through coordination meetings. Evaluation can be done while the program is running and after the program is running. For this reason, the evaluation of training activities has always been carried out. Evaluation can also be done with monitoring carried out through the WhatsApp group with the housewives as Program targets. After the program is implemented, the housewives are asked to write their impressions and messages after the training activities have begun.

\subsection{Termination}

The last stage is the termination. This stage is the stage of formal termination with the target community. For this stage, it has been carried out in Ratu Jaya Village, several programs are considered to be running well. Like the Women Farmer Group program outside Ratu Jaya, it continues to run even though the activity has been going on for a year. For the Cipayung village, the Program is still being provided and monitoring is continuing through WhatsApp groups that have been made so that it makes it easy to share information directly.

\subsection{Challenges and obstacles in implementing the Program}

Supporting Factors in the successful implementation of the Program cannot be separated from the role of the City Government of Depok in supporting the Program activities. There is good collaboration, coordination, and communication across sectors between the agencies involved. It also cannot be separated from the support and commitment of local stakeholders who actively participated in the activities provided. The enthusiasm of poor housewives to learn skills is quite large. There is also good cooperation and participation from disadvantaged housewives in participating in the training activities provided 
There are also inhibiting factors in the implementation of the Program, including a lack of community knowledge so that the activities provided are difficult to develop further, the lack of confidence of housewives in applying the training that has been received so that often the training that has been given is not reapplied to the maximum, The lack of time given during the training so that it cannot be maximized in providing such training until poor housewives can apply it, and the lack of capital provided after the skill activities are given, so that poor housewives find it quite difficult to start their businesses.

The supporting and inhibiting factors are also felt by the housewives as a target of the Program. Supporting factors for housewives in participating in the Program activities are the large role of cadres and hamlet/neighborhood who are encouraging them to participate in training activities. The spirit of these housewives in participating in the skills activities provided so that the implementation can run well. Training activities are felt to provide additional knowledge for them, also encourage them to start a business from the skills provided. As well as training activities provided under the specialization of disadvantaged housewives

Inhibiting factors for the housewives in participating in the Program activities are lack of provision of supporting equipment provided when training is complete so that not all underprivileged housewives can apply the training that has been obtained. Lack of time given when mothers participate in training activities so that underprivileged housewives can not be maximized when practicing these activities. The lack of tools needed after training to support underprivileged housewives re-practiced the training they had received. In the Women Farmer Groups activity there is no water tank, so they have difficulty watering their plants, especially during the dry season, the presence of animals/pests is a barrier when the crops are damaged by the animals/pests, and the lack of capital owned by housewives to open their businesses.

Relating to the determination of the community empowerment strategy, it is seen that there are general weaknesses in the determination of the empowerment strategy, which only focuses on empowering the main actors, namely the community and their families [20]. The success of empowerment is often determined by the quality of the facilitator and the perception of the regional leader as the sole authority in his position as a government administrator and a development administrator. Also, the success of empowerment requires the support of many parties related to the activities that are disseminated or to be carried out $[1][21][22]$.

\section{Conclusion}

Basically, in the Program training activities, the government through agencies has tried very well to provide activities in the form of training for indigent housewives. However, indigent housewives are unable to re-hone the skills that have been given. Of course, this is also the presence of obstacles, it seems there is not enough capital and tools to implement in the future. This is a consideration when giving training, whether in the future an indigent housewife will be able to develop it independently. Henceforth, it can be used as reference material as an additional business capital for indigent housewives so that the skills they receive can be a source of their economic income.

In Ratu Jaya Village, after being given training through the Program there are still routine activities such as Women Farmer Group. For food processing, cake delivery and make-up are additional knowledge which is still practiced by indigent housewives. Henceforth 
in Cipayung Village, the Program is still running. So that the training activities provided are still being monitored and developed so that these women can work independently.

\section{References}

[1] A. Huraerah, Social Protection Policy Theory and Application of Dynamic Governance. Bandung: Shades of Cendikia, 2019.

[2] K. U. Noer, "Mereka yang Keluar dari Rumahnya: Pengalaman Perempuan Madura di Bekasi," J. Ina. Kaji. Peremp. Indones. di Drh. Tertinggal, Terdepan, dan Terluar, vol. 1, no. 1, pp. 5574, 2018

[3] N. Shafwah, "Perempuan VS Kemiskinan," Kompasiana, 2018. [Online]. Available: https://www.kompasiana.com/kahilah/perempuan-vs-koverty_550058f6813311791bfa7565.

[4] Pemerintah Kota Depok, "10 RW Terlibat Dalam Program P2WKSS," Pemerintah Kota Depok, 2018. [Online]. Available: https://www.depok.go.id/16/05/2018/01-berita-depok/2019-10-rwelected-in-program-p2wkss.

[5] E. Suharto, "Building Communities Empowering People," Bandung (ID): Refika Aditama, 2005.

[6] K. U. Noer, "Land, marriage and social exclusion: the case of Madurese exile widow," Procedia-Social Behav. Sci., vol. 65, pp. 180-185, 2012.

[7] B. Suwandi, "Understanding Qualitative Research," PT Rineka Cipta, Jakarta, 2011.

[8] B. Bungin, "Qualitative Research: Communication, Economics," Public Policy, Other Soc. Sci. Jakarta Kencana, 2007.

[9] P. Irawan, "Qualitative and Quantitative Research for Social Sciences," Jakarta Dep. Adm. Sci. FISIP-UI, 2006.

[10] L. J. Moleong, "Metode Penelitian Kualitatif, Cetak Ke-12," Bandung PT Remaja Rosdakarya, 2000 .

[11] J. R. Raco, Metode penelitian kualitatif. Gramedia Widiasarana Indonesia, 2010.

[12] E. Suharto, "Pekerjaan Sosial di Dunia Industri: Memperkuat Tanggungjawab Sosial Perusahaan (Corporate Social Responsibility)," Bandung: Refika Aditama, 2007.

[13] W. Creswell Jhon, "Reseach Design Pendekatan Kualitatif, Kuantitatid dan Mixed." Pustaka Pelajar. Yogyakarta, 2013.

[14] Pemerintah Kota Depok, "Renstra," Pemerintah Kota Depok, 2018. [Online]. Available: http://cipayung.depok.go.id/pemerovernment/renstra.

[15] I. R. Adi, Intervensi komunitas: pengembangan masyarakat sebagai upaya pemberdayaan masyarakat. Rajawali Pers (Rajagrafindo Persada), 2008.

[16] O. M. Anwas, "Community Empowerment in the Global Era," Alf. Bandung, 2013.

[17] V. Moeljarto, "Pemberdayaan Kelompok Miskin Melalui Program IDT," dalam Onny S. Prijono dan AMV Pranarka, 1996.

[18] A. I. Rukminto, "Pemberdayaan, Pengembangan Masyarakat dan Intervensi Komunitas," Jakarta Lemb. Penerbit Fak. Ekon. Univ. Indones., 2003.

[19] S. Sugiyono, "Research Method Quantitative and Qualitative R\&D," Alf. Bandung, 2010.

[20] T. Mardikanto and P. Soebiato, "Pemberdayaan masyarakat dalam perspektif kebijakan publik," 2012.

[21] Depok Raya News, "P2WKSS Ratujaya Depok Terbaik di Jawa Barat," Depok Raya News, 2018. [Online]. Available: https://depokrayanews.com/p2wkss-ratujaya-depok-terbaik-di-jawabarat/.

[22] B. S. Waryoko, "Strategi pemberdayaan pemuda indonesia:(Studi kasus pemuda di organisasi kemasyarakatan pemuda (OKP) di propinsi DKI Jakarta).” Universitas Indonesia. Program Pascasarjana, 2009. 